NBER WORKING PAPER SERIES

THE INSTITUTIONS OF MONETARY POLICY

Mervyn King

Working Paper 10400

http://www.nber.org/papers/w10400

NATIONAL BUREAU OF ECONOMIC RESEARCH

1050 Massachusetts Avenue

Cambridge, MA 02138

March 2004

The views expressed herein are those of the author(s) and not necessarily those of the National Bureau of Economic Research.

(C2004 by Mervyn King. All rights reserved. Short sections of text, not to exceed two paragraphs, may be quoted without explicit permission provided that full credit, including $(\mathrm{C}$ notice, is given to the source. 
The Institutions of Monetary Policy

Mervyn King

NBER Working Paper No. 10400

March 2004

JEL No. E0, G0, H0

\section{ABSTRACT}

I argue that it is useful to think about the optimal design of monetary institutions using the insights from the theory of incomplete contracts. The core of the monetary policy problem is the uncertainty about future social decisions resulting from the impossibility and the undesirability of committing our successors to any given monetary policy strategy. The impossibility stems from the observation that collective decisions cannot be enforced so that it is impossible to commit to future collective decisions, The undesirability reflects the fact that we cannot articulate all possible future states of the world. Monetary institutions expand the possibility frontier of the technology of collective decisions by raising the costs of making inefficient deviationsng from pre-announced paths. Institutions also become repositories of experience and knowledge to facilitate learning about the economic environment and communication to society as a whole. I illustrate the importance of institutional design for the operation of monetary policy by reference to three case studies: the collapse of exchange rate regimes in Brazil and the United Kingdom; currency arrangements in Iraq and their reform after the 2003 war; and the relationship between central banks and governments when the zero constraint on nominal interest rates is binding.

Mervyn King

Governor

Bank of England

Threadneedle Street

London EC2R 8AH

ENGLAND

and NBER

mervyn.king@bankofengland.co.uk 


\title{
THE INSTITUTIONS OF MONETARY POLICY
}

\author{
Mervyn King*
}

To have one central bank governor address you today may be regarded as a misfortune, but to invite two looks like carelessness!

It is a great honour to be invited by this year's President-Elect, Marty Feldstein, to deliver the Ely lecture. Marty has been my teacher, mentor, colleague and friend for over thirty years, and I never cease to be amazed by the energy and imagination which he devotes to the study of economic problems.

I got to know Marty during my time as a Kennedy Scholar at Harvard in 1971. The Kennedy Scholarships form one part of Britain's national memorial to President Kennedy. The other part is an acre of land, now American territory, at Runnymede. At the ceremony to open the Runnymede memorial in 1965, Prime Minister Harold Wilson remarked about President Kennedy that "his eyes were on the horizon, but his feet were on the ground". Almost thirty years earlier Richard T. Ely published his autobiography entitled "Ground under Our Feet". Whereas I found the experience of coming from Europe to the United States intellectually liberating and exhilarating, a hundred years earlier Ely found academic freedom by making the reverse journey. As he wrote in his autobiography, "When I first went to Germany I seemed to breathe a new and exhilarating atmosphere of freedom ... [which] did not exist in [American universities]" (Ely, 1938). Two journeys, separated by a hundred years, reveal much about what occurred in Europe and America between them. Upon his return, Ely "undertook to draw up a project for the formation of a society to be called 'The American Economic Association', which should be broad enough to appeal to all the 
younger economists who, irrespective of their personal views, felt the stirring of the new life in economics". His actions helped the AEA to develop into the great institution it is today.

I have the privilege to work for another great institution, the Bank of England. And, as we celebrate the 150th anniversary of Ely's birth, I thought it would be appropriate to choose as the theme of my lecture today the role that institutions play in the conduct of monetary policy. In brief, I want to argue that the core of the monetary policy problem is uncertainty about future social decisions resulting from the impossibility and the undesirability of committing our successors to any given monetary policy strategy. The impossibility stems from the observation that collective decisions cannot be enforced so that it is impossible to commit to future collective decisions; the undesirability reflects the fact that we cannot articulate all possible future states of the world. It is not possible collectively to commit to enforce a monetary policy contract with an institution such as a central bank. And, even if we could, we would not want to because that would prevent us from exploiting new knowledge about the world. In essence, I want to argue that the relevant theoretical framework could be described as "public goods meet incomplete contracts". Institutional design is at the heart of collective decisions in a world of incomplete contracts, and, interestingly, discussion of monetary issues in recent years has focussed on institutional arrangements.

I shall illustrate the importance of institutional design for the operation of monetary policy by reference to three case studies: the collapse of exchange rate regimes in Brazil and the United Kingdom; currency arrangements in Iraq and their reform after the war last year; and the relationship between central banks and governments when the zero constraint on nominal interest rates is binding.

Money and monetary policy can be traced back to the dawn of civilisation itself. In contrast, central banks are a recent development. The first central bank was the Riksbank in Sweden, set up in $1668^{1}$. To celebrate its tercentenary it endowed the Nobel Prize in Economics. The Bank of England, the oldest continuing central bank, opened for business in 1694. Our tercentenary was a more low-key event: we published a book of conference proceedings. By 1900 there were still only 18 
countries with a central bank. Today the number is 174 . The Federal Reserve has yet to reach its centenary. As institutions go, most central banks are youthful. Indeed, the reputation of central banks as wise and disciplined institutions, in contrast with the wild excesses of finance ministries, belies their respective ages. So the history of monetary policy cannot be equated with the history of central banks. But it is a story about institutions.

\section{Externalities in the Theory of Money}

In the history of money, the two key events are the emergence of a medium of exchange and the rise of institutions governing its management. Those events raise two basic questions which are central to understanding the nature of monetary institutions. First, why did money evolve as a social or public rather than a private institution? Second, how can societies reduce the costs of being unable to make commitments about future collective decisions? The answers to these two questions determine the nature of modern central banks.

The two questions relate to two different externalities. The first is a network externality. Money overcomes the constraint of the double coincidence of wants implied by barter exchange, a view set out in detail by Carl Menger (1892) and which is modelled explicitly in Nobuhiru Kiyotaki and Randall Wright (1989). More recently, the existence of money has been linked to the information structure of the economy. Agents have imperfect information about their potential trading partner's credit history which explains the emergence of a private sector medium of exchange as an alternative to an extension of credit (Narayana Kocherlakota, 1998). Our willingness to use and hold money is greater the more that money is used by other people. There is, therefore, a network effect.

One can imagine, and indeed Friedrich Hayek (1976) advocated, a system in which anyone is allowed to issue money. The private sector may well co-ordinate on using the money of the 'best' issuer, and that issuer's behaviour may be kept in check by the threat of entry. But competitive monies have arisen only rarely and in situations where government money is either absent (as, for example, in Robert Radford's (1945) study of cigarette money in POW camps) or very badly managed (as in periods of 
hyperinflation). Despite the abolition of foreign exchange controls, as recommended by Hayek, competition among national currencies has not lessened the dominance, within each economy, of a single public money. Network externalities make it difficult for competing currencies to emerge.

The existence of public money generates a second type of externality to do with intertemporal choices. The willingness to hold money as either a store of value or a means of payment, or use money as a unit in which contracts are denominated, depends upon expectations of the stability of the value of that money. If money takes the form of competing private currencies then there is no inherent problem for private issuers to maintain the value of their liabilities by backing them appropriately, a commitment that can be enforced by the legal system. Alternatively, where a private commodity standard is the solution to the exchange problem, then there is no ability and therefore no temptation - to devalue. But a public monopoly means that the demand for money today depends upon expectations of our collective decisions about the supply of money tomorrow. The key question for a public currency is how do we prevent the government - ourselves - abusing its issuing power in the future? Collective decisions today cannot bind future collective decisions. And when monetary policy is set period by period inefficient outcomes result. The key insight of Finn Kydland and Edward Prescott (1977) was that the inability to make commitments leads to a failure to internalise the impact of public policies on the expectations of the private sector.

Dynamic inconsistency was used by Kydland and Prescott (1977) and Robert Barro and David Gordon (1983a) to demonstrate that rational expectations could lead to an equilibrium in which inflation was higher than desired. Ex post it would always seem attractive to create surprise inflation. More recently, research by Lars Svensson (1997), Michael Woodford (2003) and others has shown that even when there is no inflation bias there can be a "stabilisation bias" from the exercise of discretionary monetary policy: one that would lead to a suboptimal combination of output and inflation variability. Those results have prompted a large volume of research exploring different ways in which the commitment to price stability could be made credible. And central banks themselves have devoted no less energy to establishing the importance of their credibility. 
Two very different approaches to the time-consistency problem have been discussed in the literature. One examines contractual relationships between the public and monetary decision-makers that reduce or eliminate the degree of inflation and stabilization biases resulting from discretionary policy. Examples include formal adoption of monetary policy rules, a contract between government and central bank instructing the latter to target price stability, the delegation of monetary policy to a conservative central banker, and investment in a reputation by current decisionmakers. But those answers from the literature on rules versus discretion are not really solutions. They only move the time-consistency issue one step back - the policy rule may be abandoned, the central banker fired, the contract reinterpreted or rewritten. ${ }^{2}$

The other approach says that real central bankers do not and need not worry about time-inconsistency; they "just do it", (Bennett McCallum, 1995). Central bankers should simply resist the temptation to deviate from the time-inconsistent policy, and private agents will eventually come to accept that resolve. Attractive as such a solution may appear to central bankers, it fails to answer the challenge posed by the game-theoretic result of Kydland and Prescott. And it fails to explain why it is that some countries in some periods just do it and others do not. Central bankers who have the determination and strength of purpose to "take the punch bowl away just when the party is getting going", in McChesney Martin's memorable phrase, clearly have the "right stuff" - so why don't they "just do it"? ? $^{3}$ A deeper explanation of how this problem can be overcome requires an analysis of what might be called the "technology of collective decisions".

Individual agents can make contracts because they believe that the legal system is external to both parties to the contract. But it is difficult to write contracts that commit future collective behaviour. Collectively, we can either meet our previous commitments or we can ignore them. To take just one example: only a few weeks ago ECOFIN, the council of economic and finance ministers of the European Union, decided to suspend the excessive deficit procedure - a key feature of the Stability and Growth Pact - that had been initiated against France and Germany. Ernst Welteke, the President of the Bundesbank, has since raised serious doubts about whether politicians 
in Europe are willing to embrace the collective fiscal discipline, backed up by real sanctions, that is necessary to prevent fiscal free-riding inside a monetary union. ${ }^{4}$

\section{The Role of Institutions}

The technology of collective decisions describes the feasible set of institutional arrangements that can be constructed to reduce the costs of the commitment problem. That problem may lead to inefficient outcomes - the Coase theorem does not apply to collective decisions. ${ }^{5}$ It is useful to think about the optimal design of monetary institutions using the insights from the theory of incomplete contracts. That theory discusses what contracts would look like if certain aspects of the world could not be verified by an outside enforcer of the contract. In terms of monetary policy, there are two related though distinct aspects of the commitment problem. First, the inability to enforce commitment, because monetary arrangements can always be changed in the absence of an outside enforcer, means that no such arrangement is sacrosanct for all time. Thomas Jefferson believed that the US Constitution should be rewritten every 20 years or so at a new constitutional convention. ${ }^{6}$ Second, we cannot fully describe an optimal monetary arrangement because we do not know all possible states of the world and hence the policy rule to which we would like to commit. Those two aspects of the technology of collective decisions create a role for institutions.

But they differ in important ways. If there were only a commitment problem, then we could describe an optimal state-contingent monetary policy reaction function. Mechanisms could then be devised to make it less likely that policy would deviate from this optimal plan - perhaps by writing the optimal rule in the form of a constitutional provision which could be overturned only by a substantial majority, or financing deficits by issuing index-linked debt. Such mechanisms would make it incentive compatible collectively to stick to the optimal plan. None of this would have come as a surprise to the authors of the American Constitution. In Federalist Paper No.10 James Madison points out that "our governments are too unstable"(p173) and in No. 37 he writes: "the people of this country, enlightened as they are with regard to the nature ... of good government, will never be satisfied till some remedy be applied to the vicissitudes and uncertainties which characterise the 
State administrations"(p243). Outside observers agreed. In 1835 Alexis de Tocqueville wrote that, "the authority which public men possess in America is so brief and they are so soon commingled with the ever changing population of the country that the acts of the community frequently leave fewer traces than events in a private family. .... The instability of administration has penetrated into the habits of the people".

The stability of institutions is, therefore, one of their greatest assets. Barro and Gordon (1983b) assumed the existence of an ongoing government or central bank which had an interest in preserving a reputation for "good" behaviour. A substantial literature, reviewed by Nancy Stokey (2002), analyses the circumstances in which it is attractive for a "good" government to distinguish itself from a "bad" government. Stokey shows that if it is not easy to do so, then it may be optimal to impose a monetary policy rule on all governments in order to reduce the damage done by the prospect of a bad government in the future. But how can society convince itself that it can eliminate bad government by adopting a policy rule? A really bad government will simply restore discretion to itself. Good and bad governments are not independent actors. They reflect the degree of consensus on how to construct institutions that will pursue consistent objectives.

The experience of high and variable inflation itself can be an important force shaping public attitudes towards the design of institutions to control it. Differences among cohorts may lead to variations over time in the optimal shape of institutions, rather as Jefferson advocated. For example, Robert Shiller (1996) reports that 90\% of those born before 1940 in Germany agreed with the statement that 'The control of inflation is one of the most important missions of German economic policy', compared with $51 \%$ of those born from 1950 onwards. Memories of hyperinflation can be vivid: Niall Ferguson cites the diary of one Frankfurt resident in 1923: "it was more than disorder that smashed over people, it was something like daily explosions... the smallest, the most private, the most personal events always had one and the same cause; the raging plunge of money"(p154). So it is not surprising that the generation of Germans which created the Bundesbank saw it as a crucial component of their new constitution. Countries, or indeed cohorts, which have not experienced hyper- 
inflation may be more willing to adopt monetary arrangements that are less entrenched in constitutional form than the post-war generation in Germany.

The second aspect of the technology of collective decisions that creates a role for institutions is our ignorance of all possible future states of the world. That means that even if we were able to commit to a policy rule, we would choose not to do so. The exercise of some discretion is desirable in order that we may learn. The most cogent argument against the adoption of a fixed monetary policy rule is that no rule is likely to remain optimal for long. Nor is this just a question of learning about parameter values. That would yield an optimal state-contingent procedure for updating the monetary policy rule. It is that we are unwilling to commit now never to learn from future experience. So we would not want to embed any rule deeply into our decisionmaking structure, such as giving it the force of law or making it part of the constitution. Instead, we delegate the power of decision to an institution that will implement policy period by period exercising "constrained discretion". The status and purpose of such institutions can be embedded into the law or constitution, which may increase the cost of reversing the delegated powers, but the optimal policy path should be open to change in response to learning. Since we cannot hope to describe ex ante what it is we expect to learn, and since new ideas are unlikely to be uniformly recognised and instantly accepted, it may be sensible to delegate both the immediate policy decision and the process of learning to the same institution. ${ }^{7}$

An interesting example of seeking flexibility to allow for learning occurred during the writing of the US constitution. One draft clause specified that Congress should be allowed to "...emit bills on the credit of the United States". There was a debate on a proposition to strike out the clause. Madison's notes describe George Mason's position on the subject: "Though he had a mortal hatred to paper money, yet, as he could not foresee all emergencies, he was unwilling to tie the hands of the legislature" . Edmund Randolph was of a similar opinion: “... notwithstanding his antipathy to paper money, [he] could not agree to strike out the words, as he could not foresee all the occasions that might arise."

So the ideal is a framework that will implement what we currently believe to be the optimal monetary policy strategy and will deviate from that only if collectively we 
change our view about what that strategy should be. Our ignorance is too pervasive to allow the adoption of a rule for how learning should occur. So if it is sensible to delegate both policy decisions and the process of learning to institutions such as central banks, that in turn requires those institutions to have political legitimacy and an acceptance that they will not redistribute income and wealth in favour of some groups rather than others at the expense of the objective given to them. ${ }^{9}$ Where such institutions are difficult to create, the 'external effect' - as Stokey (2002) called it - of good monetary policy will not be captured. And if the result is a monetary policy that is sufficiently bad, it may result in a radical switch to a unit of account determined externally, an obvious example of which is dollarisation.

Monetary institutions, therefore, play two different roles. First, they expand the possibility frontier of the technology of collective decisions and can be designed to raise the cost of those decisions deviating from pre-announced contingent paths. Second, they are set up explicitly to exercise a degree of discretion - "constrained discretion" - subject to the broad objective of price stability. Discretion is inevitable because of the need to learn about the economic environment. Institutions thereby become repositories of experience and knowledge which they communicate to society as a whole.

\section{Case Study I: Exchange Rate Regimes in Brazil and the UK}

I want to illustrate the importance of institutions and the credibility of their stability by three case studies. My first example concerns the collapse of exchange rate regimes in Europe and Latin America. It demonstrates that economic institutions require a broad base of political support if financial markets are to believe that those institutions are likely to survive.

For a while fixed exchange rate regimes enjoyed a degree of support in both Europe, with the Exchange Rate Mechanism (ERM), and Latin America. But experience shows that, in terms of credibility in financial markets, the design of those policy regimes was less important than the fact of their having broad political support. 
Brazil in 1998-99 is a case in point. In 1998 Brazil operated a crawling peg exchange rate regime. As can be seen from Chart 1, throughout that year markets expected the Real to depreciate as evidenced by the fact that the implied forward exchange rate was lower than the spot rate by more than the crawl would imply. ${ }^{10}$ In order to defend the crawling peg, the central bank raised interest rates in September 1998 from $20 \%$ to $40 \%$ a year. The implied forward exchange rate promptly fell. Raising interest rates actually increased the expectation that the peg would be abandoned, since markets knew that high interest rates were likely to prove politically unsustainable. Any government prepared to keep interest rates that high was not likely to win re-election. In January 1999 a second speculative attack on the peg occurred. And this time the peg was abandoned. Although short-term interest rates were raised while the peg was being defended, they were soon lowered to more sustainable levels. The expectations that had been built into forward exchange rates were proved correct.

[insert chart 1 here]

In the literature on target zones for exchange rates, it is assumed that raising interest rates is a successful method for supporting the exchange rate because of uncovered interest parity. But this ignores the possibility that raising interest rates to defend a fixed exchange-rate regime will simply call into question the durability of the regime itself and raise the probability that the peg or target zone will be abandoned. In such circumstances an increase in interest rates may lead to a fall in the exchange rate.

A second example of the same phenomenon is the pressure on sterling during 1992 and its forced departure from the Exchange Rate Mechanism on 16 September of that year. Massive speculation on that day led to the announcement in the morning of a 2 percentage points rise in interest rates and, when that failed to dampen the pressure on sterling, of a further 3 percentage points rise in rates. That second announcement, far from bolstering the exchange rate, merely convinced financial markets that Britain's membership of the ERM could no longer be sustained politically. The strong political commitment to joining European monetary union, which was the effective support for other currencies in the ERM, was absent in the United Kingdom. 
Following its departure from the ERM, the UK introduced an inflation target regime for monetary policy. It succeeded in bringing inflation down to around $21 / 2$ percent (see chart 2).

[insert chart 2 here]

But long-term inflation expectations did not fall as quickly. Only after the announcement in May 1997 by the new Labour government that the Bank of England would be made independent did inflation expectations fall quickly to the target level, as can be seen from chart 2. That reform created an expectation that it would be in the interests of all political parties not to repeal the legislation. For the first time since the Second World War, there was a broad-based and credible commitment in the UK to stable and low inflation.

The need for any monetary regime to command sufficient support in order to acquire a reasonable life-expectancy was given insufficient weight in the discussions that took place at the IMF and elsewhere on Brazil and other financial crises of the 1990s. The point is made by Guillermo Calvo and Frederic Mishkin (2003) when they write, "the key to macroeconomic success in emerging market countries is not primarily their choice of exchange rate regime, but rather the health of the countries' fundamental macroeconomic institutions, ... less attention should be focused on the general question whether a floating or a fixed exchange rate is preferable, and more on these deeper institutional arrangements"(p5). ${ }^{11}$

\section{Case Study 2: Currency Reform In Iraq}

The importance of expectations about the future of monetary institutions is illustrated by the recent monetary history of Iraq. This second case study demonstrates that expectations of future collective decisions can have a major impact on the value of a currency quite independently of the policies pursued by the current government. Expectations of monetary decisions within a given policy regime may be less significant than expectations of changes in the regime itself. In Iraq, regime change took on a new meaning. What is particularly interesting about Iraq is the link between expectations of a change in political regime and movements in currency values. 
Prior to the Gulf War in 1991 the Iraqi currency was the dinar. Following that war Iraq was divided into two parts that were politically, militarily and economically separate from each other: southern Iraq was under the control of Saddam Hussein and the enforcement of the northern no-fly-zone meant that northern Iraq became a de facto Kurdish protectorate. In the South, Saddam's regime struggled to cope with UN sanctions, and resorted to printing money to finance growing fiscal deficits. Unable to import notes printed abroad because of sanctions, the regime printed low-quality notes in Iraq that bore Saddam's image. In May 1993, the Central Bank of Iraq announced that the 25 dinar note, then the highest denomination note in circulation, would be withdrawn and replaced by a new locally printed note. These were known as 'Saddam' or 'print' (because of the offset litho print technology used) dinars. Citizens had three weeks to exchange old for new notes. So many notes were printed that the face value of cash in circulation jumped from 22 billion dinars at the end of 1991 to 584 billion only four years later. Inflation soared to an average of about $250 \%$ a year over the same period. As a result the smaller denomination notes became worthless in Southern Iraq.

In the North, however, matters were rather different. Residents in that part of Iraq had no opportunity to exchange their notes. And it was no accident that, because of expropriation of cash in the banks by the Saddam regime, the holders of the high denomination notes were disproportionately in the North. Of the seven billion 25 dinar notes in circulation in Iraq at that time, about five billion circulated in Kurdishcontrolled Iraq. So the Saddam dinar did not circulate in the North, and the old dinar notes continued to be used. They were known as the 'Swiss' dinar-so- called because although the notes had been printed by the British company De La Rue, the plates had been manufactured in Switzerland. The Swiss dinar developed a life of its own and in effect became the new currency in the North. No Swiss dinar notes were issued after 1989, and since there was no issuing authority there was at most a fixed, and probably a declining money stock in the North. As a result the Swiss and Saddam dinars developed into two separate currencies.

For ten years, therefore, Iraq had two currencies: one issued by the official government and the other backed by no government at all. The Swiss dinar continued 
to circulate in the North, even though backed by no formal government, central bank, nor any law of legal tender. For a fiat currency this was an unusual situation. Whatever gave the Swiss dinar its value was not the promise of the official Iraqi government, or indeed any other government. ${ }^{12}$

Although there was little or no trade between North and South Iraq, both the Swiss and Saddam dinars were traded against the dollar. The implied Swiss to Saddam dinar cross-exchange rate from 1997 onwards is shown in Chart $3{ }^{13}$

\section{[Chart 3 here]}

After 1993 the Swiss dinar deviated from parity and rose to around 300 Saddam dinars to the Swiss dinar by the time Saddam's regime was deposed in 2003. The appreciation of the Swiss dinar is clearly a consequence of the evolution of the actual and expected money supplies in the two territories.

Given the monetary and fiscal policies pursued by the Saddam regime, the rise of the Swiss dinar against the Saddam dinar is, perhaps, understandable. But what is less obvious is the path of the Swiss dinar against the US dollar. Chart 4 shows the Swiss dinar-dollar exchange rate from 1997 onwards.

[insert Chart 4 here]

After fluctuating in the early 1990s, the Swiss dinar rose sharply against the US dollar from the middle of 2002 as the prospect of an end to the Saddam regime increased. It rose from around 18 to the dollar in May 2002 to about 6 to the dollar by the beginning of May 2003 when the war ended. That appreciation reflected expectations about (i) the durability of the political and military separation of Kurdish from Saddam-controlled Iraq and (ii) the likelihood that a new institution would be established governing monetary policy in Iraq as a whole that would retrospectively back the value of the Swiss dinar. The political complexion of Northern Iraq led to the assumption that the currency used there would have value once regime change had occurred. 
In other words, the value of the Swiss dinar had everything to do with politics and nothing to do with the economic policies of the government issuing the Swiss dinar because no such government existed. As someone might have said, "it's the political economy, stupid!"

Another illustration of this is shown in Chart 5 which plots the Swiss dinar/dollar exchange rate against the values of futures contracts showing how expectations about the political order in Iraq were evolving.

[Insert Chart 5 here]

One futures contract paid out 100 cents if Saddam was deposed by the end of June 2003 and nothing otherwise. As the chance of Saddam's regime being deposed (and the price of the future) rose, the Swiss dinar appreciated against the dollar. Later there was also a future that paid 100 cents if Saddam was captured by the end of December 2003, and nothing otherwise. As the chance of this happening (and the price of the future) fell last autumn, the Swiss dinar fell against the dollar. It has just risen again. Again, expectations about the future political order in Iraq, which have repercussions for the likely monetary regime in northern Iraq, influence the value of the Swiss dinar today.

Much of this was understood by Kurds in the North where the exchange rate of the Swiss dinar to the dollar was a matter of both concern and interest. The minutes of a meeting of the Kurdish Regional Government on 14 October 2002 state: "KRG Prime Minister Nechirvan Barzani chaired a meeting to discuss the ongoing problem of the weak US dollar in the local currency markets. Discussion focussed on the ... unprecedented $45 \%$ decrease in the value of the US dollar against the Iraqi Swiss dinar, possible causes of the problem, and effects on the market". Realising that the effect of a change in the exchange rate cannot be understood without an analysis of the causes of the change, the minutes continue, in a manner that would do justice to the minutes of any G7 central bank, "It was pointed out that the US dollar is currently stable in foreign markets so there must be other explanations for the sharp slide in value in Iraqi Kurdistan". ${ }^{14}$ In other words, an explanation was needed for a rise in the real value of the Swiss dinar. 
Of course, as we now know, the expectation that a future institution guaranteeing the integrity of the Kurdish area, and of the value of their currency, turned out to be correct. Coalition forces assumed control of the whole territory, and on 7 July 2003 the head of the Coalition Provisional Authority, Paul Bremer, announced that a new Iraqi dinar would be printed and exchanged for the two existing currencies at a rate that implied that one Swiss dinar was worth 150 Saddam dinars. The exchange was to take place over the period 15 October to 15 January. It is now virtually complete. The new dinars, like the Swiss, were printed by De la Rue in a very short space of time using plants in Britain and several other countries, and were flown into Iraq on 22 flights using Boeing 747 and other aeroplanes. The fact that the populations of both North and South Iraq have been prepared to exchange their old notes for new dinars reflects the confidence which they have in the future of the institutions backing the new Iraqi dinar.

The 150 parity is barely half the rate the Swiss dinar reached at its peak (see Chart 6).

[insert Chart 6 here]

But it is above the average rate that prevailed over the past six years, and above the rate that would equalise the purchasing power of the two currencies. For example, around the time when the new conversion rate was being determined, it was estimated that 128 Saddam dinars to the Swiss would equalise the wages of an engineer in the two parts of Iraq, 100 would equate the price of the shoes he wore to work, and 133 the price of his suit. ${ }^{15}$

From Chart 6, it is clear that the exchange rate hovered above 150 after the parity was announced on 7 July. There are two reasons for this. First, the 10,000 Saddam dinar note was heavily counterfeited, easy to do given the primitive local technology used to print them. The exchange rate of this note against the dollar is consistently less than the 250 dinar note which, as a smaller denomination note, was less heavily counterfeited. The Swiss notes, printed using more sophisticated technology, are virtually free of counterfeits. The Swiss notes traded at above the parity because of the risk that holders of the 10,000 note would find that they had a forgery and could 
not exchange it at the central bank. Second, before the capture of Saddam Hussein there was inevitably some uncertainty about the prospects of the new regime and the new currency that it issued.

The circulation of Swiss dinars in Kurdish controlled Iraq during the 1990s was a market solution to the problem of devising a medium of exchange in the absence of a government with the power to issue currency. Changes in the relative price of Swiss and Saddam dinars show that the value of money depends on beliefs about the probability of survival of the institutions that define the state itself.

\section{Case Study 3: Monetary Policy in Japan and the Zero Bound on Interest Rates}

My third case study shows that institutional arrangements need to be consonant with the underlying economics, or failure will result. Recent experience in Japan has led to the rebirth of interest in monetary policy when official interest rates are constrained by the zero lower bound. Official short-term interest rates in Japan have been approximately zero since the beginning of 1999. Of particular interest in this context is the question of how responsibilities should be divided between the central bank, on the one hand, and the finance ministry, on the other.

Guy Debelle and Stanley Fischer (1994) introduced the distinction between instrument and goal independence of central banks. That distinction has become the standard framework within which to analyse the optimal constitution of central banks. But such a distinction presumes the existence of a policy instrument that is uniquely availlable to the central bank. That instrument is the level of official short-term interest rates. But when interest rates are constrained at their lower bound of zero, the position is much less clear. Indeed, I shall argue that in such circumstances both instrument and goal independence are impossible. Rather when interest rates are at their zero lower bound, policy relies on successful cooperation between central bank and finance ministry.

I shall assume that, when interest rates are zero, monetary policy takes the form of open market purchases or sales of government securities using central bank money. 
A well-known policy prescription, which has become known as unconventional monetary policy, is that the central bank should buy long-term Government bonds rather than the more conventional short-term bills. The Bank of Japan did indeed follow this prescription. The logic of such a proposal is as follows. Long-term bonds are likely to contain a significant premium to compensate investors for their lack of liquidity - the fact that, in practice, investors face significant costs when switching between bonds and goods. When the central bank offers to buy illiquid long-term bonds, it increases the average liquidity of the private sector's portfolio, replacing less liquid with more liquid securities. The private sector will therefore be more willing to hold other illiquid instruments, such as private sector bonds and equities. As a result, liquidity premia fall across a broad category of securities, raising their market value. That will stimulate spending by firms and consumers. ${ }^{16}$ Such a policy is preferable to conventional open market purchases of short-term bills or bonds because when interest rates are zero such bills become perfect substitutes for cash. Hence purchases of short bonds have no effect on spending or other real variables.

It is a short step to show that this argument implies an equivalence proposition between unconventional quantitative operations, on the one hand, and a combination of neutral conventional operations and government debt management, on the other. The purchase of a long-term bond by the central bank is equivalent to a combination of two other operations: a purchase of a short-term bill, followed by an operation that swaps the short-term bill for the long term bond. In either case, the central bank balance sheet ends up with an additional liability in cash, and an additional asset in long-term bonds. The first of these two operations, the purchase of a short-term bill, is neutral in its effect as it replaces one private sector asset, a short-term bill, with another, cash, that is a perfect substitute for it. The second is debt management, which is normally seen as the responsibility of the finance ministry. So when interest rates are zero unconventional quantitative operations and debt management are indistinguishable.

The interplay between monetary policy and debt management may not matter too much when short-term interest rates are positive because the central bank can control the level of interest rates, even if debt management affects the optimal level of rates. But when rates are at their zero bound then the central bank no longer has instrument 
independence. Indeed, because its actions can be offset by appropriate sales or purchases in the government debt market, it loses goal independence too. It becomes crucial that fiscal and monetary authorities cooperate. An alternative strategy, equivalent in terms of its monetary effects but avoiding the risk to the Bank of Japan's balance sheet from holding large quantities of government bonds, would have been for the Ministry of Finance to have issued short-term bills to the BoJ, using the proceeds to purchase and retire long-term government bonds. Similar arguments apply to other unconventional monetary policies, such as purchases of foreign currency, which conflict with the responsibilities of the fiscal authorities for the ownership of foreign exchange reserves.

A serious problem for the Japanese authorities was that the Bank of Japan was granted independence not long before it became necessary for policy to be coordinated between MoF and the BoJ. ${ }^{17}$ Inevitably, the desire on both sides to respect the newlywon independence of the central bank came into conflict with the growing realisation that monetary policy was operating in a zero-interest rate environment. The clarity of communication about the objectives of monetary policy diminishes when it is no longer possible to identify clear and distinct responsibilities for the two institutions. A desirable long-term reform - central bank independence - led to short-term difficulties.

\section{Conclusions}

I am conscious that I have raised more questions than I have answered - perhaps that is what happens when you become a central banker. I hope I have not copied my room-mate at Harvard whose $\mathrm{PhD}$ supervisor wrote, "he chewed more than he had bitten off". ${ }^{18}$ But the search for institutions that improve our ability to handle the two problems associated with public money - the impossibility and undesirability of committing our successors - is never ending, and our knowledge is limited. At the very first gathering of economists to create the American Economic Association, in Saratoga in September 1885, Richard Ely showed that he had the makings of a good central banker when he said, "We acknowledge our ignorance, and if we claim superiority to others it is largely on the very humble ground that we know better what 
we do not know". Or, in Hayek's words, "It is high time we took our ignorance more seriously".

The inability to bind future generations means that institutions do not resemble an optimal time-invariant design chosen from behind the "veil of ignorance". They reflect, in Hayek's words, "how nations in the darkness stumble upon institutions which are in fact the result of human actions, not the implementation of a human plan". 19

Suitably designed, though, monetary institutions can help to reduce the inefficiencies resulting from the time-consistency problem and can incorporate new ideas into a discretionary monetary strategy constrained by a mandate that has widespread support in the population as a whole. A central bank needs to explain to the population both what it knows and what it does not know. Such a framework of "constrained discretion" for central banks is far-removed from the world of 1930 when the Deputy Governor of the Bank of England explained to the Macmillan Committee that "it is a dangerous thing to start to give reasons".

In 1908 Congress set up the National Monetary Commission to report on "what changes are necessary or desirable in the monetary system of United States". Before recommending the establishment of the Federal Reserve System - a plan which it described as "essentially an American system, scientific in its methods, and democratic in its control" - the Commission produced 22 volumes on the monetary and banking systems elsewhere, especially in Europe. Copies of these volumes sit proudly in the Governor's anteroom in the Bank of England. The authors noted that "the important place which the Bank of England holds in the financial world is due to the wisdom of the men who have controlled its operations and not to any legislative enactments". But they did not see the Bank of England as a model, and they recommended the creation of an institution framed by legislation. It would be ninety years before Britain finally learnt the lessons of the National Monetary Commission and passed legislation to buttress whatever wisdom the Bank could command.

Institutions embody accumulated wisdom and experience, and they should not be meddled with lightly. From time to time, however, it is necessary to rethink the role 
of our institutions. The changes made to the Bank of England in recent years, including an inflation target and a high degree of transparency, have, I believe, improved Britain's monetary arrangements. Whether either the men and women or the current institutional arrangements of the Bank of England will have any more success in influencing monetary arrangements in the United States today than in 1908 is a matter I leave to you. 


\section{Bibliography}

Acemoglu, Daron. "Why not a political Coase theorem? Social conflict, commitment, and politics." Journal of Comparative Economics, December 2003, 31(4), pp. 620-652.

Aghion, Philippe and Bolton, Patrick. "Incomplete Social Contracts." Mimeo, Princeton University.

Barro, Robert and Gordon, David. "A positive Theory of Monetary Policy in a Natural Rate Model." Journal of Political Economy, August 1983, 91(4), pp.589-610.

Barro, Robert and Gordon, David. "Rules, Discretion and Reputation in Model of Monetary Policy." Journal of Monetary Economics, July 1983, 12(1), pp. 101-121.

Calvo, Guillermo and Mishkin, Frederic. "The Mirage of Exchange Rate Regimes for Emerging Market Countries." Journal of Economic Perspectives, Fall 2003, 17(4), pp. $99-118$.

Clower, Robert. "A Reconsideration of the Microfoundations of Monetary Theory.", Western Economic Journal, December 1967, $\underline{6}$, pp.1-9.

Debelle, Guy and Fischer, Stanley. "How independent should a central bank be?", in Jeffrey Fuhrer, ed., Goals, Guidelines and Constraints Facing Monetary Policymakers. Boston: Federal Reserve Bank of Boston,1994.

De Tocqueville, Alexis. Democracy in America. New York: Alfred A Knopf, 1945.

Dewey, David R. Financial History of the United States. $6^{\text {th }}$ Edition. New York: Longmans, Green and Co, 1918.

Ely, Richard T. Ground Under Our Feet. New York: Macmillan,1938.

Ferguson, Niall. The cash nexus: Money and Power in the Modern World, 17002000. London: Penguin/Allen Lane Press, 2001.

Hamilton, Alexander; Jay, John and Madison, James. The Federalist Papers. New York: Mentor Books, 1961.

Hayek, Friedrich A. The Constitution of Liberty. London: Routledge and Kegan Paul, and Chicago: University of Chicago Press, 1960.

Hayek, Friedrich A. Denationalization of money. London: Institute of Economic Affairs, 1976.

Issing, Otmar. "Rede aus Anlass der Verleihung des Internationalen Preises der Friedrich-August-von-Hayek-Stiftung." Speech delivered on 12 October, available at http://www.ecb.int/key/03/sp031012de.htm.

Kiyotaki, Nobuhiru and Wright, Randall. "On Money as a Medium of Exchange." Journal of Political Economy, August 1989, 97(4), pp. 927-954. 
Kocherlakota, Narayana R. "Money is Memory." Journal of Economic Theory, August 1998, 81(2), pp.232-251.

Knapp, Georg F. The state theory of money. London: Macmillon, 1905 (1924 edition).

Kydland, Finn E and Prescott, Edward C. "Rules Rather than Discretion: the Inconsistency of Optimal Plans." Journal of Political Economy, June1977, 85(3), pp. 473-491.

McCallum, Bennett T. "Two Fallacies Concerning Central Bank Independence." American Economic Review, May 1995, $\underline{85}$ (2), pp. 207-11.

Menger, Carl. "On the Origins of Money." Economic Journal, June 1892, 2(6), pp.239-255.

Persson, Torsten and Tabellini, Guido. "Political Economics and Macroeconomic Policy," in John B Taylor and Michael Woodford, eds., Handbook of Macroeconomics. Oxford: Elsevier, 1999.

Radford, Robert A. “The Economic Organization of a POW Camp', Economica, November 1945, 12(48), pp.189-201.

Sargent, Thomas $\mathbf{J}$ and Velde, Francois. "Macroeconomic Features of the French Revolution." Journal of Political Economy, June 1995, 103 (3), pp. 474-518.

Shiller, Robert. "Why do people dislike inflation?" National Bureau of Economic Research (Cambridge, MA) Working Paper no 5539, April 1996.

Stokey, Nancy. "Rules vs Discretion after 25 years." NBER Macroeconomics Annual, Cambridge, MA: MIT Press, 2002.

Svensson, Lars EO. "Optimal Inflation Targets, 'Conservative' Central Banks and Linear Inflation Contracts." American Economic Review, March1997, 87 (1), pp. 98 114.

- "Comments on Nancy Stokey, 'Rules vs Discretion after 25 years'." NBER Macroeconomics Annual, Cambridge, MA: MIT Press, 2002.

- "What Is Wrong with Taylor Rules? Using Judgement in Monetary Policy through Targeting Rules." Journal of Economic Literature, June 2003, 41, pp. 426-477.

Vidal, Gore. Inventing a Nation: Washington, Adams, Jefferson. New Haven and London: Yale University Press, 2003.

Woodford, Michael. Interest and Prices. Princeton: Princeton University Press, 2003. 


\title{
NOTES
}

\begin{abstract}
* Governor, Bank of England, Threadneedle St, London EC2R8AH. These remarks were delivered as the Richard T Ely lecture at the American Economic Association meeting on January 32004 . I am deeply grateful to James Proudman, Jan Vlieghe and Tony Yates for their research collaboration and for many of the ideas in this lecture. They are truly co-authors. I am also grateful to Peter Andrews, Andrew Bailey, John Campbell, Forest Capie, Philip Evans, Niall Ferguson, Charles Goodhart, Simon Gray, Oliver Hart, John Moore, Tom Sargent, Lars Svensson, Greg Thwaites and Geoffrey Wood for their helpful comments. Kath Begley and Ed Bolingbrooke provided valuable research assistance. All errors and omissions are my responsibility.
\end{abstract}

\footnotetext{
' Strictly speaking, it is not clear that the Riksbank was what we would today recognise to be a central bank until considerably later.

${ }^{2}$ Torsten Persson and Guido Tabellini (1999) argue that if it takes sufficient time for a government to tear up contracts designed to eliminate the inflation bias (longer than the duration of nominal contracts) promises not to inflate can be credible.
}

${ }^{3}$ Svensson (2002) takes the same view of McCallum (1995) in his comments on Stokey (2002), thus: “...to my knowledge neither McCallum nor anyone else has presented a model where 'just do it' is an equilibrium outcome."[p4].

4 "The institutional structure of monetary union forms the basis for public trust in the euro and rests on two pillars: the stability-oriented monetary constitution enshrined in the Maastricht treaty, and the stability and growth pact. Both pillars are being undermined, leaving European monetary union in a very grave predicament". (Ernst Welteke, The Times, 4 December 2003).

${ }^{5}$ Daron Acemoglu (2003) argues that inefficient policies can occur in a democracy because those in political power cannot commit to maintaining the policies that are required to achieve efficient outcomes. In other words, the Coase theorem does not apply at the level of society as a whole.

${ }^{6}$ As reported by Gore Vidal (2003).

${ }^{7}$ Svensson (2003) takes a view that is related to the argument here. In his opinion, commitment to 'targeting rules' - objectives that the central bank must pursue - are workable, while commitment to 'instrument rules" - reaction functions - are not, since it is "impossible" that "every conceivable contingency be anticipated" [p439].

${ }^{8}$ This is cited in David Dewey (1918), page 68.

${ }^{9}$ The costs and benefits of discretion in a world where we cannot describe future possible states of the world are set out in Philippe Aghion and Patrick Bolton (2002).

${ }^{10}$ The forward rate was below the spot rate even allowing for the devaluation implied by the crawling peg.

${ }^{11}$ This quote appears on page 5 of the NBER working paper number 9808 (Cambridge, MA) version of their paper. At the time of writing, the Journal of Economic Perspectives version, which appears in the list of references, was still forthcoming.

${ }^{12}$ At no stage did the Kurdish groups lay claim to the Swiss dinar as their currency - they had no control over it - as shown by the interview given to Gulf News on 30 January 2003 by the Kurdistan Regional Government Prime Minister Barzani who said, "We don't have our own currency".

${ }^{13}$ Sources for these data include the United Nations (from the oil-for-Food program) and the Central Bank of Iraq.

${ }^{14}$ The minutes are archived on the KRG web site www.krg.org/news. 
${ }^{15}$ Source: compiled by the Central Bank of Iraq, based on data collected by the United Nations World Food Program.

${ }^{16}$ How large are these effects is an open question. The absence of a compelling general equilibrium theory of liquidity makes it difficult to produce reliable empirical estimates. For the purposes of the equivalence proposition the magnitude of the effect is irrelevant.

${ }^{17}$ The legislation was published in 1997, and took effect in April 1998.

${ }^{18}$ The supervisor (in English literature) was citing a letter from Mrs Henry Adams to her father, December 1881: "Its not that he bites off more than he can chaw as T.G. Appleton said of Nathan, but he chaws more than he bites off." (Nathan was Appleton's son). The remark is also sometimes attributed to Mark Twain as a comment on Henry James' writing.

${ }^{19}$ Hayek (1960), cited by Otmar Issing (2003). 
Chart 1: Exchange rates and monetary policy in Brazil, Jan 1998-Dec 1999

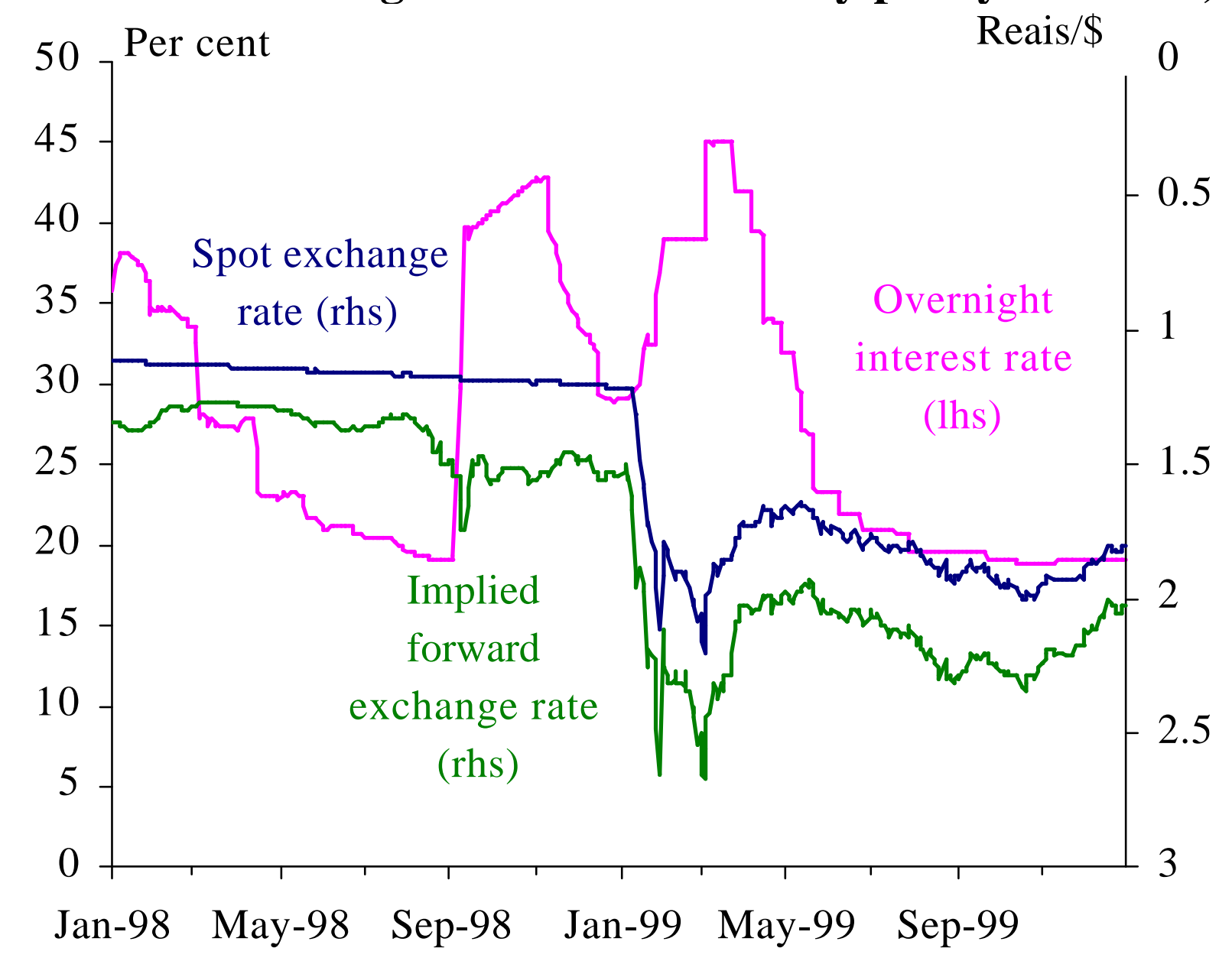

Source: JP Morgan and Banco Central do Brasil 


\section{Chart 2: UK intiation and intiation}

expectations, Oct 1991- Oct 2003

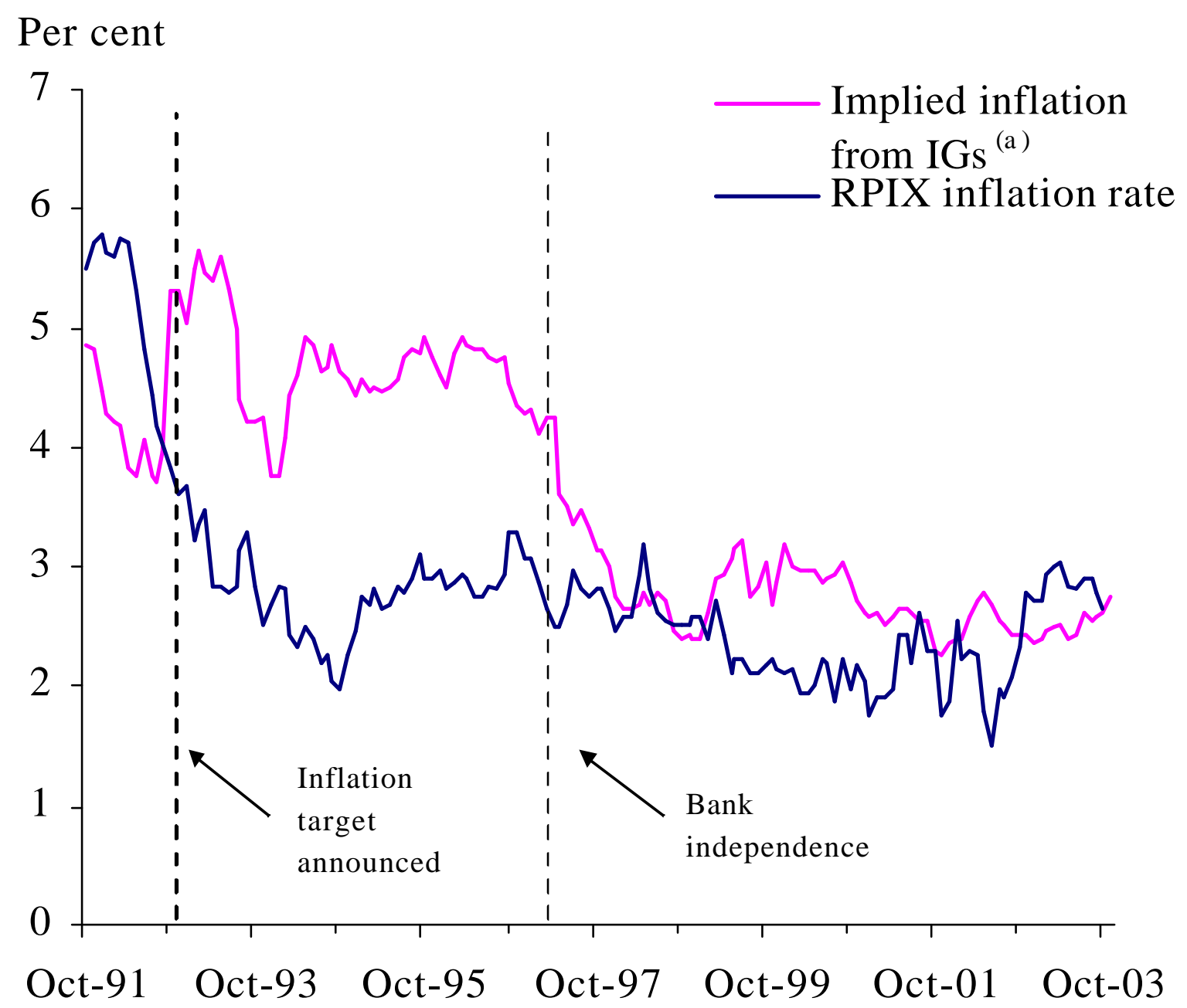

(a) Implied average inflation expectations from 5 to 10 years ahead, derived from index-linked gilts. Source: Bank of England, ONS 
Chart 3: Saddam/Swiss Dinar exchange rate, Jul 1997-Oct 2003

Saddam/Swiss Dinars

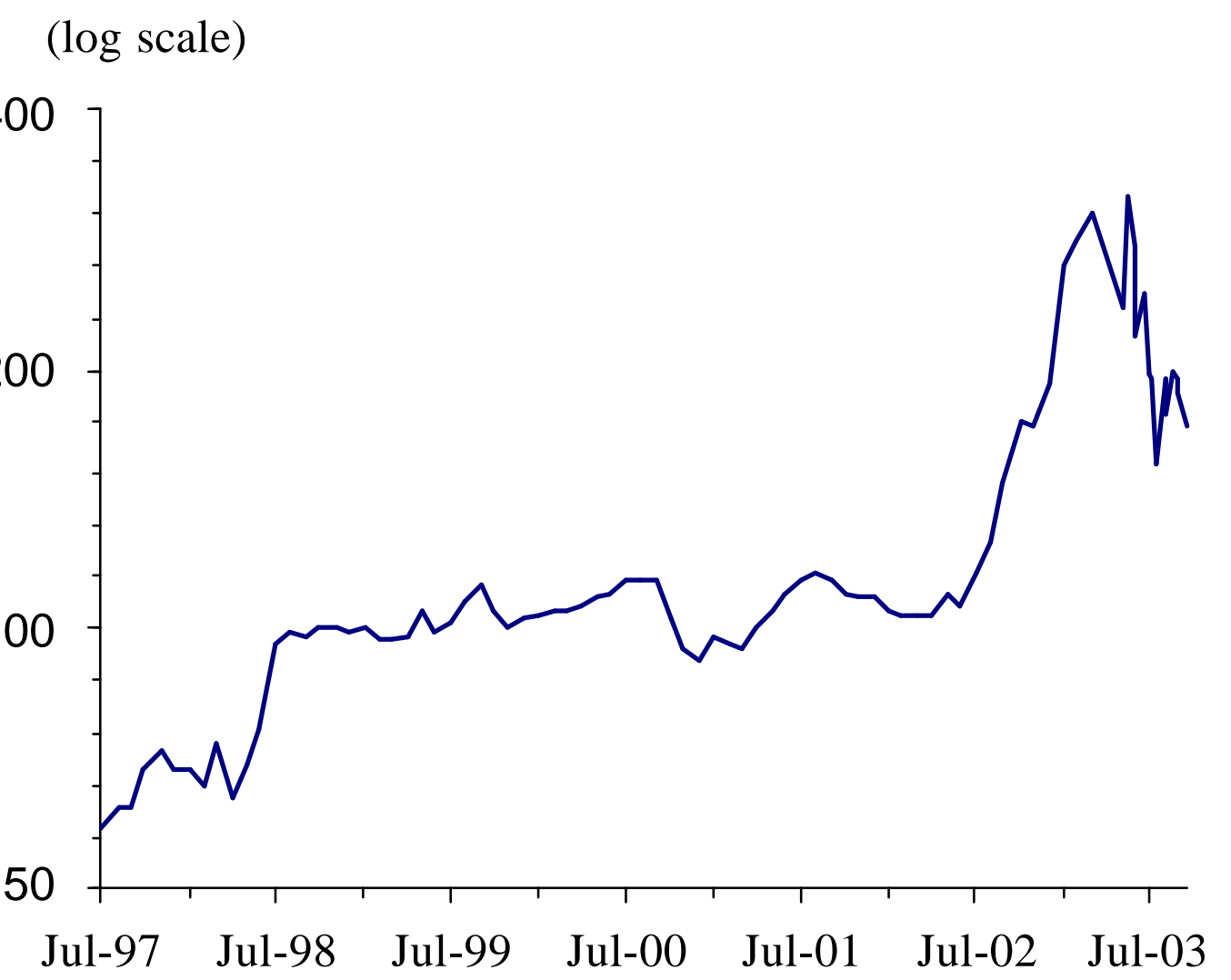

Source: United Nations, Central Bank of Iraq 
Chart 4: The Swiss Dinar/Dollar exchange rate, Jul 1997-Oct 2003

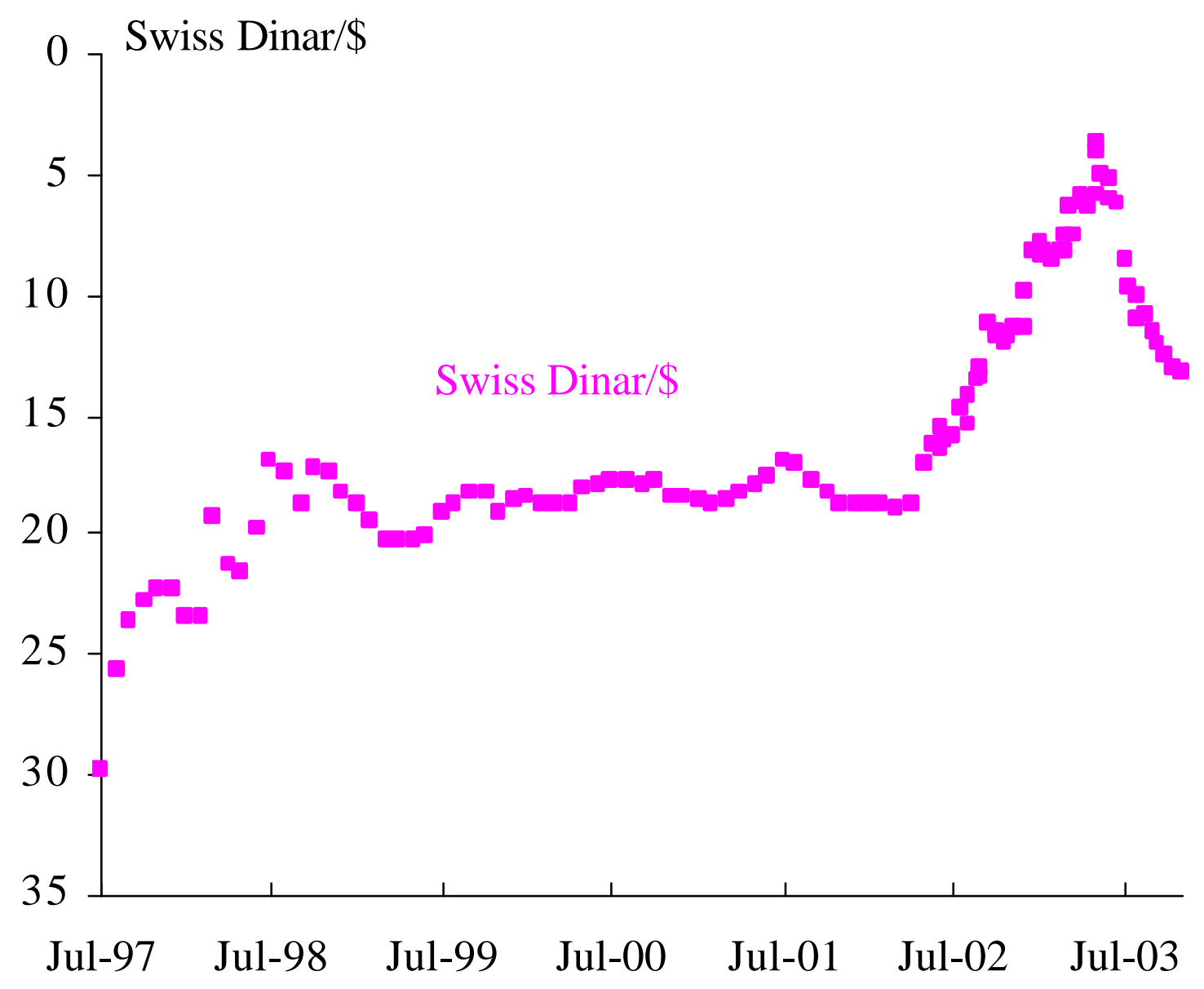

Source: United Nations, Central Bank of Iraq 


\section{Chart 5: Exchange rates and regime change}

in Iraq, Sep 2002- Dec 2003

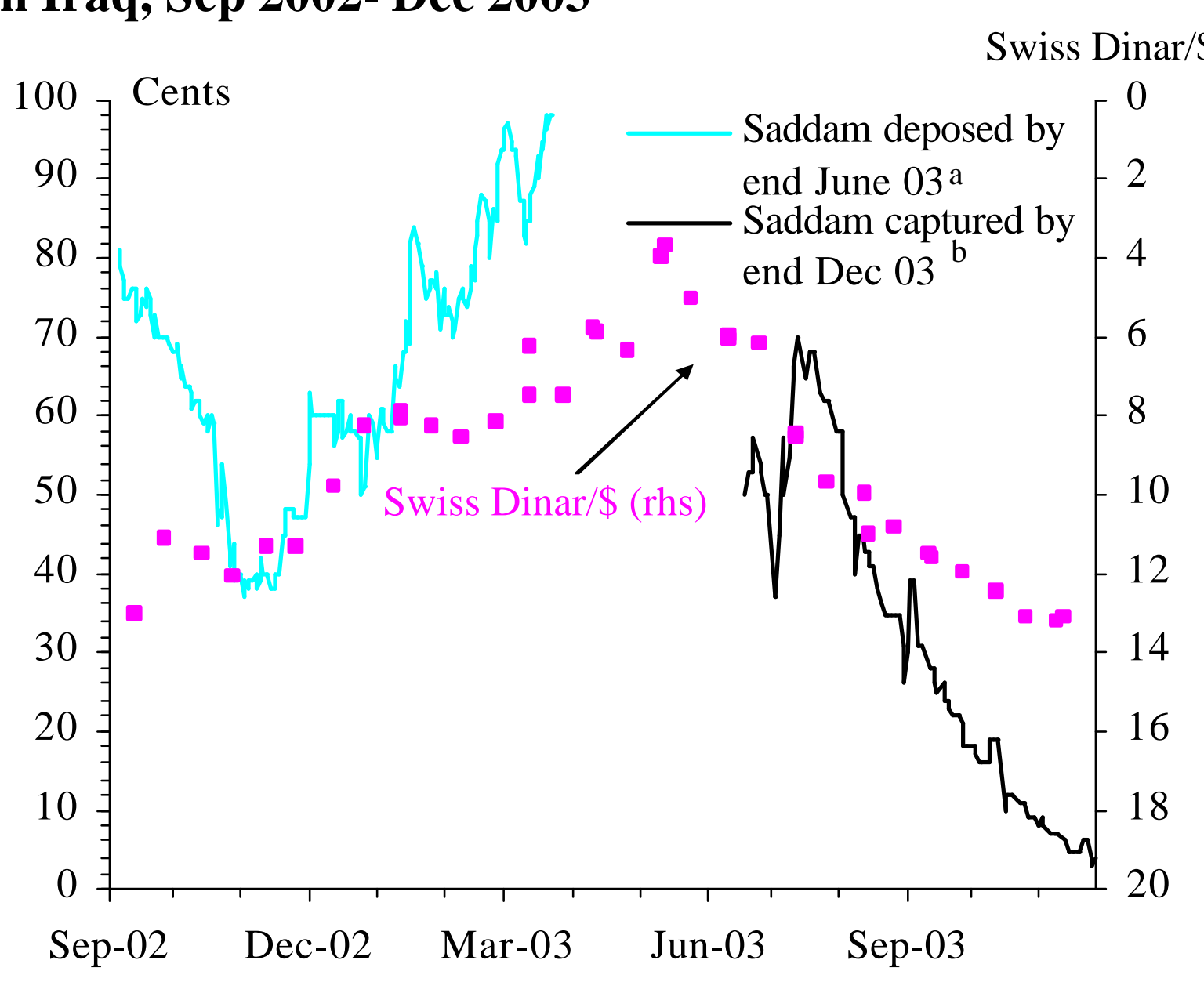

Source: United Nations, Central Bank of Iraq, Tradesport Exchange Limited

(a) Value in cents of a contract that paid 100 cents if Saddam is deposed by the end of June 2003, and 0 otherwise

(b) Value in cents of a contract that paid 100 cents if Saddam was captured by the end of December 2003, and 0 otherwise 


\section{Chart 6: The Saddam/Swiss Dinar}

exchange rate, Jan 2002-Dec 2003

Saddam/Swiss Dinar

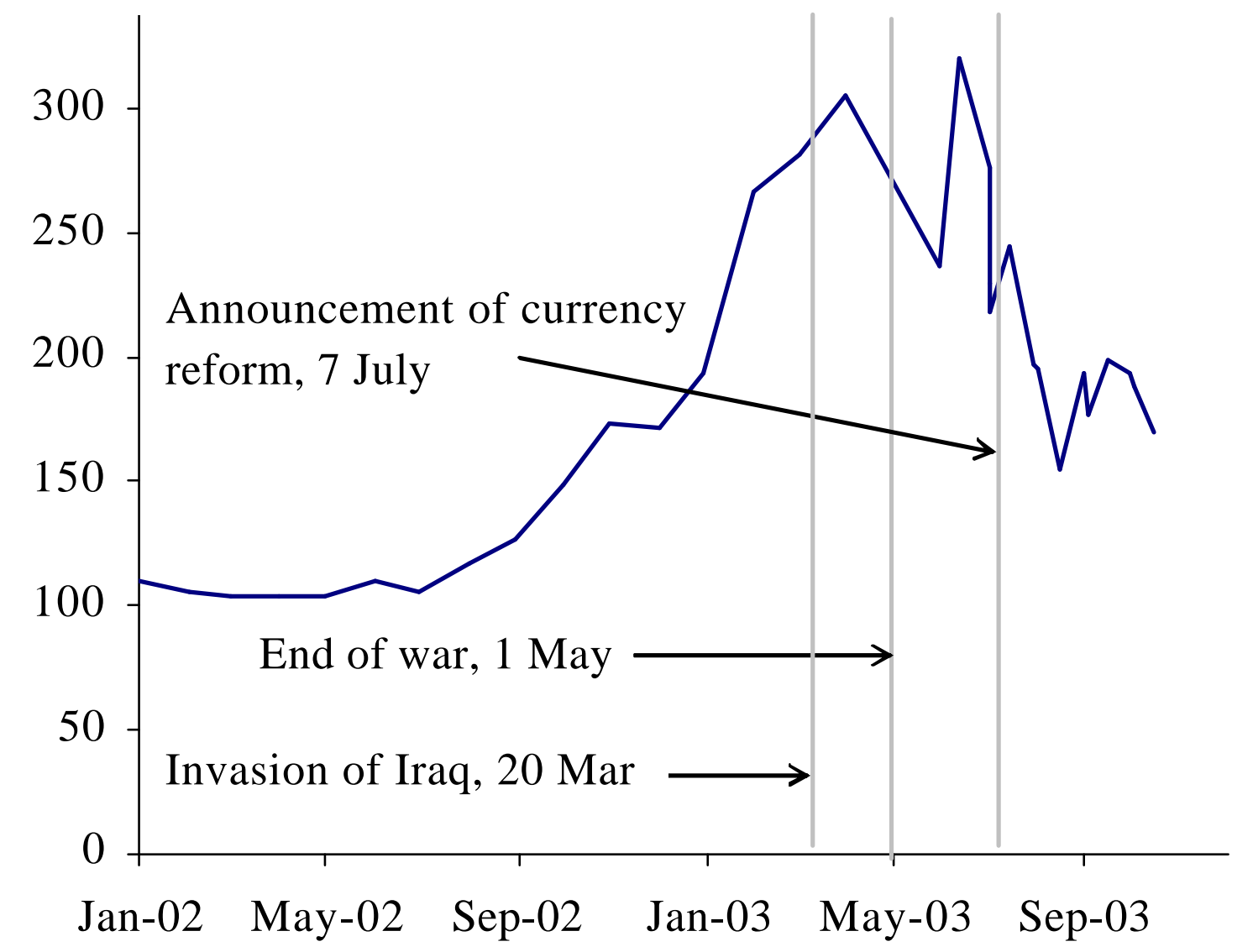

Source: United Nations, Central Bank of Iraq 